\title{
For an archeology of online participatory literary writing: Hypertext and hyperfiction
}

\author{
Francesca Pasquali ${ }^{1}$ \\ Università degli Studi di Bergamo, Italy
}

\section{doi:10.5937/comman1430045P}

Summary: This article analyzes one of the roots of contemporary online participatory writing practices within the literary field, focusing on an object that had its theoretical heyday twenty years ago: hypertextual fiction. Invented in the sixties by social informatics visionary Ted Nelson, the word "hypertext" gained academic attention in the humanities in the early nineties with the works (among others) of George P. Landow, Paul Delany, David Bolter and Stuart Moulthrop. In 1992, in his review of Michal Joyce's Afternoon (still credited as one of the first pieces of hypertext fiction) Robert Coover (1992) wrote in The New York Times Book Review: "much of the novel's alleged power is embedded in the line [...] [T]hrough print's long history, there have been countless strategies to counter the line's power [...] but true freedom from the tyranny of the line is perceived as only really possible now at last with the advent of hypertext, written and read on the computer, where the line in fact does not exist unless one invents and implants it in the text". Since then, hypertext started to be defined as an artefact empowering the reader to subvert the linear text and the author's authority, and thus, within a post-structural and postmodern theoretical framework, deconstructing and subverting the very roots of power tout court. By addressing hypertext theory (a mixture of history of textual forms, of reading practices, and of technologies of memory, semiotics, poststructuralist and feminist theory, etc.) and tracing the influences of postmodern literature and the literary avant-gardes on hypertext fiction, the article will thus investigate both the construction of hypertext as a participatory "cultural object" - in Wendy Griswold's (1994) terms - and the legacy of that theoretical debate and those artistic practices in contemporary reflections on online collaborative literary writing.

Keywords: hypertext, collaborative fiction, literary theory, history of computing, media archaeology, cultural participation

\footnotetext{
1 francesca.pasquali@unibg.it
} 


\section{Introduction}

According to the Oxford English Dictionary, which first recorded its existence in 1993, a hypertext is a "text which does not form a single sequence and which may be read in various orders", providing "text and graphics [...] interconnected in such a way that a reader of the material (as displayed at a computer terminal, etc.) can discontinue reading one document at certain points in order to consult other related matter" (Simpson and Weiner, 1993). Digital hypertexts had been first developed in the second half of the sixties; it was only in 1987, however, that they gained public attention when Apple decided to install on its computers free hypertextual software, called Hypercard. In the same year the Association for Computing Machinery (ACM) held the first conference entirely dedicated to hypertext and hypermedia (AAVV, 1989).

In the following years hypertexts became very fashionable, to the point that Norman Meyrowitz's² (1989) speech at that ACM conference debunked its rhetoric as he wondered whether hypertext would "reduce cholesterol, too". Hypertexts were not only fashionable, however: they were one of the most successful areas of experimentation in computer sciences and their associative structure was extremely influential in the developing of the world wide web at the beginnings of the nineties. In 1999 the website of the 10th ACM Conference on hypertext and hypermedia was opened by this statement: "much has changed in this field since the first workshop in 1987. Most notably, the WWW became a de-facto standard and brought the notion of hypertext to millions of users" (http://www.kom.e-technik.tu-darmstadt.de/\%7Eht99/). This statement is the best acknowledgment of the hypertext success; paradoxically, it also acknowledges the fact that hypertext, as such, had become obsolete, collapsing under the success of the hypertextual structure of world wide web.

Nowadays, hypertexts may be little more then a curiosity for media archaeologists, but going back to that debate, with all its hype and rhetoric, can still be of some interest not only for those interested in the development of digital literature but also for scholars investigating, more broadly technological mediated practices of participation. From 1987 to the mid-nineties, hypertexts become an interdisciplinary crossroads, connecting people interested in humancomputer interaction, social informatics, literary theory and the arts. Hypertext

\footnotetext{
2 Norman Meyrowitz is the creator of Intermedia, a didactic hypertextual system used in the eighties at Brown University.
} 
theory (a mix of informatics, history of textual forms and reading practices, semiotics and post-structuralism, feminist theory, etc.) was indeed one of the main fields where people started to reflect on what happens when author/text/ reader interaction meets interactivity. Moreover, relying on a series of different circumstances (circumstances that we will address later on), hypertext was "shaped" by hypertext theory as a participatory tool useful for subverting the dominant cultural paradigm.

Starting from a social shaping of technology (SST) approach, this essay will investigate the construction of hypertext as a participatory "cultural object" i.e. a shared significance embodied in form (Griswold, 1994).

Thinking of hypertext as "cultural object" - more than as a technology and / or medium -means working on it as a construct, investing the term "hypertext" itself with social meanings that cross both the history of hypertext as technological artefact and the history of "hypertextuality" as a theoretical definition of a specific type of text.

From a SST-perspective, the "material" production and adoption of a technological artefact cannot be separated from the discourses and imaginaries that surround it and that, in turn, needs to deal with the various concrete configurations of the technology in itself (see for example Flichy, 1995). In this perspective the history of hypertext technology and the history of the idea of hypertext in their intermingling become the place of articulation of what Carolyn Marvin (1988) defines the "common sense" of a technology that drives (although not exclusively and not hegemonically) the way in which a new cultural resource is distributed and embedded in society.

After addressing both the history of hypertext as a technological artefact and hypertext theory (and the influences of postmodern literature and the literary avant-gardes on hypertext fiction) the essay will discuss some of the contradictions of that debate still relevant for those interested in participation in and through the media (Carpentier, 2007) in the contemporary cultural environment. There hypertext is nothing more than a curiosity for media archaeologists, while users' participation, spanning from increased interactivity to content generation, has become more present in the literary field - not to mention the artistic field (Graham, 2010) - and definitely common in contemporary cultural scenarios. 


\section{Hypertexts and the "home computer revolution"}

The first major area of discourse that built hypertexts as participatory texts is connected with the emergence, in the sixties, of a number of theories and visions on emancipatory and political uses of informatics.

Hypertext is placed within the fundamental intersection (described by Flichy, 1999, 2001) between the academic computational culture and Californian countercultures that shaped - well before the material advent of personal computers (Ceruzzi, 1998) and computers networks (Abbate, 1999) - the idea of computers and computer networks as a means of social interaction. These technological developments soon became seen as resources for empowering both individuals and communities.

From Vannevar Bush's (1945) Memex (an analogue mnemonic machine considered to be among the precursors of the hypertext idea) through Douglas Engelbart's oN-Line System (Nyce and Kahn, 1991) from the 1960s, the hypertext associative structure is indeed linked to the idea of mind-machine isomorphism: hypertexts were in fact recognized as sophisticated, interactive "tool for thought" (Rheingold, 2000) empowering personal intellectual performances and creativity.

However, if we look at the social history of hypertextual technology we see that the definition of hypertexts as "tools for thought" (Rheingold, 2000) blurs with another powerful idea that started to spread in the late sixties: the idea of computers as "tools of conviviality" (Pasquali, 2003). In the developing of hypertexts, a significant role was in fact played by the new cultural climate of the seventies, when computer cultures merged with a broader counter-cultural political framework, with the consequence that computers started to be defined as amplifiers of imagination and as a means of personal and collective emancipation (Levy, 1984; Woolley, 1992). Close to pacifism, ecology movements, pop culture and the "psychedelic revolution", anti-authoritarian computer subcultures of the west coast positioned themselves against the exclusive connection between computer research and the academic, economic, military and political establishments. The idea was to make technologies accessible, transforming them from "instruments of oppression" into "tools of liberation" for society and of personal creativity. More politically oriented groups, close to the civil rights movements, also played an important role, igniting different projects meant to bring computer resources to communities and the people. Projects like Com- 
munity Memory - established in 1973 in Berkeley and credited to be the first public, computerized BBS - were designed around the idea of low cost computers as a resource of democratization and civic participation (Crosby, 1995). Quoting Ivan Illich's (1973) influential book, we might say computers started to be considered "tools of conviviality", extracted (both in their production and use) from technocratic control and incorporated into common people's everyday life. In this complex scenario, mirroring the cultural and political participatory orientation of sixties' counter-cultures and social movements (Carpentier, Dahlgren and Pasquali, 2014), computers stood for "symbols of hope for a new populism in which citizens would band together to run information resources and local government" (Turkle, 1984: 172).

Hypertexts were at the very heart of this scenario, thanks to one of its pioneers, Ted Nelson, whose books can be considered a real manifesto of the new convivial sensibility. In The Home Computer Revolution (1977), for example, Nelson envisioned the advent of direct, immediate, personal and domestic uses of the computer: a new computing era in which interaction was no longer framed in its mere technical dimension, but was conceived in its fully cultural dimension as a form of participation in public life. In Computer Lib/Dream Machine (1974), Nelson had also proclaimed the "liberation" of the computer from big industries control and a computer-enhanced "liberation", and he has defined computers as "dream machines" and as the new frontier of personal freedom and democracy. In Computer Lib, Nelson stated that the importance of computers resides not only in their capacity for calculation, but also in the fact that they would enable new generations of media undertakings with the audience in mind (Wardrip-Fruin and Montfort, 2003: 301).

These new media experiences should be designed within a radical, open publishing network that Nelson was studying since the mid-sixties when he conceived the Xanadu project (from ST Coleridge's Kubla Khan): a universal publication system (inspired by literary intertextuality) based on computer networks and on digital text with an associative architecture (Nelson, 1990). The goal of Xanadu was the democratization of knowledge through the expansion of access to information, increased possibilities of interaction with the content, and the possibility for users to participate directly in the creation of new content. To define this project, in 1965, Nelson coined the word "hypertext" (Nelson, 1992). 


\section{Hyperfiction, interactive fiction and postmodern narrative}

Soon after its Apple diffusion to the broader public and its ACM canonization as a specific area of study, hypertext software started to be used in order to write novels and fictional texts. While Michael Joyce's Afternoon (1987-1992) is probably the only hypernovel known by the wide literary public, there are other "classic" literary hypertexts like John McDaid's Uncle Buddy's Phantom Funhouse (1991), Stuart Moulthrop's Victory Garden (1991a), Jayne Yellowlees Douglas' I Have Said Nothing (1994), Shelley Jackson's Patchwork Girl (1994), and those collected in the 1991 special issue of the UC Davies creative writing journal Writing on the Edge (Moulthrop, 1991b), as well as the "constructive" (Joyce, 1988) hypertext novels Hypertext Hotel started by Robert Coover in 1992/1993 and The Unknown by William Gillespie, Scott Rettberg, Dirk Stratton and Frank Marquardt (1999).

After the limited but highly significant popularity they gained in the early nineties, hypernovels continued to be produced both offline and on the web, and today hyperfiction is part of the bigger literary field named "electronic literature"3. Pieces of hyperfiction were for example published in the Cybertext yearbook 2000-2006 (http://cybertext.hum.jyu.fi/index. php?browsebook=8and), some were included in the Electronic Literature Collection published by Electronic Literature Organization (Hayles et al., 2006; Borràs et al., 2011), while some others were presented at the Electronic Literature Exhibit at the Modern Language Association 2012 Convention (http:// dtc-wsuv.org/mla2012/). However, within electronic literature, hyperfiction constitutes a very coherent literary corpus (Ensslin, 2007) that has raised its own critical practices devoted to the study of hypernovels within a very broad network of cultural references, both digital and in print.

Even if hyperfiction is much more complex in its textual structure and in the levels of interactivity it allows (Ryan, 2005), it has been compared, for example, to "interactive fiction": a genre of fictional textuality, whose digital variations had some success in the eighties, based both on the experimentation with human/computer interaction/dialogue and with computer adventure games (Montfort, 2003).

\footnotetext{
3 We are not going to discuss here the distinction between electronic, ergodic or cyber literature. See among others Aarseth, 1997, Murray, 1997, McGann, 2001, Hayles, 2002, Landow, 2006.
} 
In tracing an archaeology of hypertext as digital text, it is impossible not to mention interactive fiction but if we look at hyperfiction as a literary genre we see a much broader network of cultural references connecting hypertext to a long tradition of literary experimentation in print. On the one side hypertext fiction is connected to the history of combinatory text and to those textgenerating mechanisms (Gitelman, 1999) that were very popular in literary avant-gardes back in the fifties and sixties (Bolter, 1991), such as William Burroughs' re-actualization of the Dadaist technique of cut-up, as well as Raymond Queneau's Cent mille milliards de poèmes (1961) and the Oulipo (Ouvroir de littérature potentielle) experiments in story making mechanisms and techniques (Campagnoli and Hersant, 1973; Eruli, 1994).

In cut-up and combinatory texts, like in hypertexts, the very materiality of the text is up for discussion; quoting Jane Yellowlees Douglas (2000), hyperfiction dialogues with other "books without pages and novels without endings" playing with printed book surface and linearity. Among the authors mentioned in establishing the hypertextual literary tradition one may find Jorge Luis Borges, Italo Calvino, George Perec and the broader (and highly controversial in its definition) field of so-called "postmodern fiction" (McHale, 1987) ${ }^{4}$. More generally, this stance can also be found in the early nineties, during the second wave (Dezeuze, 2010) of attention toward new relations between art, literary text and the audience, which became connected with digital and video art and postmodern culture (Gere and Gardiner 2010); this second wave followed the first wave, in the sixties and seventies, of participatory engagement of artistic and literary avant-garde (Popper, 1975).

In this cultural climate, it is not surprising then that the most important literary acknowledgement to hyperfiction in the nineties was awarded in 1992 when postmodern author Robert Coover reviewed Michal Joyce's Afternoon in The New York Times Book Review: "much of the novel's alleged power", Coover (1992) wrote,

is embedded in the line [...] through print's long history, there have been countless strategies to counter the line's power [...] but true freedom from the tyranny of the line is perceived as only really possible now at last with the advent of hypertext, written and read on the computer, where the line in fact does not exist unless one invents and implants it in the text.

\footnotetext{
4 It is not possible to enter here the huge debate on postmodernism and on postmodern fiction. For a synthesis see Bertens, 1995.
} 
Hypertext technology, in Coover's perspective, made it possible to achieve what postmodern fiction had tried to do for a long time: break the traditional time structure (beginning, development, end) of narration, open different plots within a story, and question the very "end" of stories. In postmodern narratives these objectives were pursued (or at least evoked) by staging a multiplicity of contradictory events and timelines, by subverting the linearity of the plot (thanks to digressions, loops, repetitions in different contexts, recursive structures, mises en abyme and metalepsis), and short-circuiting the ends of stories through the establishment of a circular pattern in the text (on the model of Joyce's Finnegans Wake) or through the suspension of all closure - e.g., Kurt Vonnegut's Breakfast of Champions (1973) concludes with the indefiniteness of the word "etc." - or through the presence of two or more mutually exclusive endings - famous examples, both published in 1969, being Robert Coover's The Babysitter and John Fowles' The French Lieutenant's Woman.

What in postmodern fiction was evoked by playing with and within the material constraints of printed books, in hypertext fiction was the norm and was embedded in its technological affordances, calling for user activity in order to actualize the different reading paths and plots within the virtual structure of pages and hyperlink of the novel.

\section{Hypertext and post-structural literary theory}

Following the popularity gained by hyperfiction in creative writing classes, and the adoption of a hypertextual system as archiving technologies and teaching tools within Humanities departments in the US, hypertexts and hyperfiction came under the focus of literary scholars (Delany and Landow, 1991, 1993).

Semiotics, narratology and reader-response criticism were invoked to frame pragmatic functioning, multilinear plot construction, and reader activity of hypertexts (Aarseth, 1997; Douglas, 2000; Liestøl, 1994; Murray, 1997; CornisPope, 2000); it was the meeting of hypertext with post-structuralism, however, that had the biggest impact in structuring the participatory aura of hypertexts. In 1992 George P. Landow published Hypertext: The Convergence of Contemporary Critical Theory and Technology, a very influential book whose opening reads: "when designers of computer software examine the pages of Glas or On Grammatology, they encounter a digitalized, hypertextual Derrida; and when 
literary theorists examine Literary Machines, they encounter a deconstructionist or poststructuralist Nelson. These shocks of recognition can occur because over the past decade critical theory and computer hypertext, apparently unconnected areas of inquiry, have increasingly converged [...] working often, but not always, in ignorance of each other; writers in these areas offer evidence that provide us a way into the contemporary episteme in the midst of major changes" (1992: 2). According to Landow, hypertext embodies Roland Barthes' (1970) "writerly" text (a text that establishes a multilateral relationship between text and reader, opening the plurality of the language that is traditionally hidden by the material surface of traditional printed text). The reader activity necessary to translate hypertexts from the potentiality of its "virtual" status to an "actual" text (Lévy, 1995 ) is the ideal answer to Michel Foucault's (1969) reflection on the disciplinary relations between print technology, the oeuvre and authorship. Barthes and Foucault were not the only ones called forth in structuring hypertext theory; in Landow's eclectic book Bachtin's polifony and multivocality are also evoked, and the deconstruction operated by hypertext of the very idea of a textual coherent body is associated to Donna Haraway's (1991) "cyborgs", a metaphor collapsing the technical, with the organic, the mythic, the textual, and the political. In Landow's perspective not only there was a perfect correspondence between hypertext's open textuality and post-structuralism: hypertext was also a participatory tool that could be of high usefulness in the classroom, directly engaging students in literary criticism and theory. In the late eighties he started three hypertext programmes, one devoted to the work of Alfred Tennyson (In memoriam Web), another devoted to Dickens' Great Expectations (the Dickens Web) and a third - a larger, and still running on the internet, project - devoted to Victorian culture (The Victorian web: http://www.victorianweb.org/misc/ vwintro.html).

While Landow $(1992,1994)$ has probably been the most influential voice in hypertheory, other scholars worked on the convergence between hypertext and post-structuralism. Gregory Ulmer (1990), for example, wrote a book comparing Jacques Derrida's deconstruction to the fluidity of hypertextual corpora that blurs the distinctions between the text and the different discourses around the text (for instance, critical discourse).

Similarly, Stuart Moulthrop (1991c: 296) defined hypertext as a "deconstructive" technology to be applied to linear texts as a tool to open their inner 
multiplicity, and elsewhere (1994) described hypertexts in terms of Deleuze and Guattari's rhizome (1980): a conceptual tool which was used (amongst other applications) for analyzing the constitution and reception of a book that allows for multiple, non-hierarchical entry and exit points in the text.

\section{The politics of hypertexts}

In the early nineties hypertexts were among the most frequently cited technologies to talk about the pluralisation of information sources and the increased access for the people (and not only for cultural élites and professionals) to content creation and management.

Hypertext was used in order to develop different projects of social interest within academia and civil society. In one of the first collections of essays devoted to hypertext (Berk and Devlin, 1991), for instance, we find two hypertexts developed in Canada by local media and devoted respectively to collect information on Hiv and to give useful information to new immigrants in the local area (MacPhail, 1991). Let's also not forget that in many US universities hypertext was hailed as a device for re-conceiving literary curricula so as to involve students, opening up a space for investigating new connections within the literary corpus, and challenging the naturalised power of the literary canon. Very ambitious under this perspective was The Brown University Women Writer Project developed in collaboration among the University of Pennsylvania, the University of New Hampshire and the Texas A\&M. The project, one that is still successfully running, was hypertextual and networked (every workstation was connected to the others via Ethernet), and it was devoted to the collection and the study of the entire female literary production, in English, in the period between 1330 and 1830, aiming to enhance the visibility of women's writing within the academic literary curricula (http://www.wwp.brown.edu). Writing and reading a hypertext, thus, was seen as a political gesture: asking for readers' performances in order to move from virtuality to actuality, hypertext started to be defined as an artefact empowering the reader to subvert the linear text and the author's authority. Within a post-structural and postmodern theoretical framework, such an artefact was claimed to deconstruct and subvert the very roots of power tout court. Hypertexts were claimed to reveal the disciplinary power of authorship, blurring the roles of the author and the reader; deconstructing text linearity, hypertexts were recognised to act upon narrative 
devices and their teleological order; in dematerializing the text, hypertexts were credited with the power to demystify the taken-for-grantedness of print culture.

In this perspective, hypertext was an example of those artistic forms that shortly afterwards began to be called "relational" art on the basis of the success of the book of Nicolas Bourriaud (1998) in which meaning is elaborated collectively through interpersonal relations, and a truly "convivial" technology (Illich, 1973), one that not only offers an open access to information but that also enhances the reader participation in the production of the text, undermining a naturalized cultural order - in fact a historical outcome of modernity (Williams, 1976) - based on the separation between production and consumption, and between author and reader (Hamilton, 2003).

Although the development of hypertext technology is firmly connected with the studies of human/computer interaction, the intersection - in the material history of hypertext - of the different discourses that we have seen above has thus loaded hypertexts with a strong participatory dimension that widely transcend the idea of computer interactivity. However, hypertext is also an interactive text ${ }^{5}$, and this circumstance does have some relevance.

In hypertext, readers' performativity is situated within a range of choices already made by the hypertext author, and it works within the interactive frame offered by the software. Only starting from a set of given options and abiding to already established interactive patterns (no matter how complex and flexible they are) the reader can structure his/her own choices.

The awareness that the participatory process is structured by hypertext interactivity entails two consequences. On the one side it shows that hypertext provides the very same freedom that was warranted in those artistic and literary works Umberto Eco (1962) named "open works": the possibilities of interaction given to readers and viewers by the works' openness, Eco acknowledged, always operates within a given field of relations, and participation is always given along an "axis spanning the two extremes of constraints and openness" (Dezeuze, 2010: 12). On the other side, exactly as in other "do-it-yourself" artwork (be it digital or not), in reading a hypertext that participation takes place within an interactive and thus controlled framework.

\footnotetext{
5 This is not the place to address the multidimensionality of the "interactivity" concept (McMillan, 2002), but beyond all the different definitions, one should not forget that interactivity is always a "style of interaction control" (Guedj et al., 1980) that enables multidirectional communication (Markus, 1990).
} 
The consonance of hypertexts with post-structuralism has been described primarily in terms of a fulfilment by hypertext technology of post-structuralist theoretical assumptions. As David Bolter (1991: 143) put it: "what is unnatural in print becomes natural in the electronic medium and will soon no longer need saying at all because it can be shown". Despite Bolter's assumptions, if we look at the tension between freedom and control in interactive textuality, it is evident that the goal of post-structuralism is not to subvert the primacy of production in favour of consumption, or the primacy of the author in favour of the reader. On the contrary, post-structuralism's main concern lies in its constant reminding of the fact that power relations are always inscribed in language and texts, and should be deconstructed in reference to specific contexts in which they perform, even when there is a reversal of power relations (from production to consumption) and when, as in hypertext, authors' authority is scaled by readers' performances.

The risks connected to the naturalization of hypertext's interactive structure (and to the betrayal of the post-structuralist ambitions) were evident to (some) scholars addressing hypertheory. Stuart Moulthrop (1991d, 1994) for instance spoke of the need to build hypertexts that had in themselves the keys of their own "deconstruction". He exemplifies this practice by looking at John McDaid's Uncle Buddy's Phantom Funhouse (1991). In this hyperfiction the tension between the opening / closing of the text is explicitly evoked through a "script" named "Porno Recursion". If activated, this script starts a loop that, in a short time, saturates the RAM, causing the shutdown of the programme and thus forcing the reader to turn off the computer. However, the reader is given the opportunity to consider the sequence of orders and to decide whether to activate the script or not: readers can make sure that nothing happens as long as they do not succumb to the seductive surface of the "Porno Recursion". In Stuart Moulthrop's (1991d: 76, 77) words, the "jump into the infrastructure in Porno Recursion gives hypermedia fiction a critical agenda" and it has the double goal to "spoil our fun, deconstruct its entertainment value, and by extension, to question the value of each 'entertainment' that is based on an interactive system". Undermining the very act of participation, the script thus draws us toward a participatory writing and reading that stimulates the readers reflectivity on their performance, positioning them between their action and the interpretation of the contextual consequences of their actions. In this per- 
spective, probably, the most important legacy of post-structuralism for a theory of hypertexts (and, more generally, for do-it-yourself art works) can be found in its work against the order of the signified, in favour of the signifier.

In hypertexts, the discursive and material devices that are used to control the text and its interpretations and meanings, are made visible (or at least can be made visible), while the reader participates in the construction / deconstruction of the text. Readers' actions on the surface of the screen (clicking links, following paths, etc.) in hypertext continuously displaces him/her from the content of the text focusing his/her attention at text's structural organization. As Richard Lanham (1989: 5) puts it: "the textual surface is now a malleable and self-conscious one ... [it] has become permanently bi-stable. We are always looking first at it and then through it - at the structure, the design and through it for the story, the concept, the point".

But of course, once again, this is not "natural". It highlights reader reflexivity on his/her reading practices both when s/he is "looking at" the text and when s/he "looks through" the text. Indeed, if on the one side the immersion in the story denies the work needed to produce the text, from the other side the automatic adherence to the patterns of interaction provided by the text itself ends by denying, paradoxically, the very conditions of participation in the production of the text opened by hypertexts.

\section{Conclusion}

In 1991 the political agenda, evoked by Stuart Moulthrop, was mainly directed against the seduction of the digital surfaces and the paradoxical "immersive" reading in the mesmerizing combinatory "surface" of postmodern fiction, which might offer, indeed, a perfect expression of Jean Baudrillard's (1981) "hyperreality". Far from being emancipatory and participatory, hypertext might provide the reader with an illusion of autonomy, while actually deeply shaping his/her reading and stifling his/her autonomy in text interpretation. Hypertext (and combinatory text) would be a form of "supervised" literature masked in the demagogic rhetoric of text democratization (Pomian and Souchier, 1988). In this perspective, hypertext was fully compromised with an issue that was raised more generally in reference to digital art and postmodern literature: they were often blamed for being "neo-conservative" both by artists, literary authors and cultural critics. For example, as pointed out by Dezeuze (2010: 12), Bruce 
Nauman's critical position toward those participatory postmodern artistic practices he defined "game playing", involve calling in its own work for the demystification of the illusion of audience participation through artistic environments that were mobilising "devices of confinement, oppression and control". While Hal Foster (1985: xii), in one of the most influential books on postmodernism, distinguishes between "postmodern reaction" and a "postmodernism of resistance", a counter-practice which on the contrary is "not only against the official culture of modernism but also to the 'false normativity' of a reactionary postmodernism. Not least we must recall Fredric Jameson's (1984) critical definition of postmodernism as the "cultural logic of late capitalism".

Today, screens and virtuality have become a substantial part of everyday life. This implies that the political agenda of digital text should be oriented towards a better understanding of the very conditions and contradiction of participation through interactivity. As we have seen, hypertheory, as well as the practice of writing and reading hypertexts and hyperfiction, have been of significant importance to historically contextualize and theoretically discuss participatory processes in digital writing and within the literary field. Placed at the convergence point of counter-cultures, post-structuralism and postmodern theory, hypertexts could embody a paradigmatic form of convivial and participatory technology.

However, if it is true - as claimed by Landow $(1992,1994)$ - that hypertext epitomises the convergence between computer science and post-structuralist literary theory, and it is configured as a radically participatory text working on the power inscribed in the language and textuality, it is equally true that this participatory value cannot claim any naturalness whatsoever.

Thanks to the shift they instigate (through the reader performativity) from the content of the text to the very conditions of textual production, hypertexts were theorized as revealing that the strong dichotomy between text production and consumption is a social and discursive constructum, not a datum. However, other scholars argued that this very same convergence between reader perfomativity and the hypertext's open structure should not become taken for granted. Otherwise there is the risk of losing all the demystifying power of hypertext, turning the participatory potentialities of interactivity into tokens of control. This is a risk glimpsed by hypertextual scholars and postmodern cultural analysts twenty years ago. Nowadays, it is seriously taken into consideration by art 
scholars who suggest that the participatory art forms and relational aesthetics have become hegemonic (Bishop, 2010) and by contemporary participatory theorists who are debating the risks and opportunities opened by the complex and ambiguous links between interactivity, connectivity (van Dijck, 2013) and participatory practices (Carpentier, 2011; Jenkins and Carpentier, 2013) within a networked society.

\section{References}

AAVV (1989). Hypertext 1987: Proceedings. New York: ACM. Accessed 28.07.2013. URL: http://dl.acm.org/citation.cfm?id=317426\&CFID=350 $354724 \&$ CFTOKEN=27351066.

Aarseth, E. (1997). Cybertext: Perspectives on ergodic literature. Baltimore: Johns Hopkins University Press.

Abbate, J. (1999). Inventing the Internet. Cambridge Mass.: MIT Press.

Barthes, R. (1970). S/Z. Paris: Seuil.

Baudrillard, J. (1981). Simulacres et simulation [Simulacra and simulation]. Paris: Éditions Galilée.

Berk, E. \& Devlin, J. (eds.) (1991). Hypertext/Hypermedia handbook. New York: Intertext/McGraw-Hill.

Bertens, H. (1995). The idea of the postmodern: A history. London, New York: Routledge.

Bishop, C. (2010). Antagonism and relational aestetics. In Dezeuze, A. (ed.), The 'do-it-yourself' artwork: Participation from Fluxus to new media. Manchester: Manchester University Press, pp. 257-280.

Bolter, J. D. (1991). Writing space: The computer, hypertext, and the history of writing. Hillsdale: Lawrence Erlbaum.

Borràs, L., Memmott, T., Raley, R., \& Stefans, B. (eds.) (2011). Electronic literature collection. Volume two. Cambridge, Mass.: Electronic Literature Organization. Accessed 28.07.2013. URL: http://collection.eliterature.org/2/ extra/about.html. 
Bourriaud, N. (1998). Esthétique relationnelle [Relational aesthetics]. Dijon: Les presses du réel.

Bush, V. (1945). As we may think. Atlantic Monthly, 176(1), 641-649.

Campagnoli, R. \& Hersant, Y. (eds.) (1973). OULIPO - La littérature potentielle (Créations Re-créations Récréations). Paris: Gallimard.

Carpentier, N. (2007). Participation and media. In Cammaerts, B. \& Carpentier, N. (eds.), Reclaiming the media communication rights and democratic media roles, London: Intellect, pp. 87-91.

Carpentier, N. (2011). The concept of participation: If they have access and interact, do they really participate?". CM: Časopis za upravljanje komuniciranjem: Communication Management Quarterly, 6(21), 13-36.

Carpentier, N., Dahlgren, P. \& Pasquali, F. (2014). The democratic (media) revolution: A parallel genealogy of political and media participation. In Carpentier, N., Schroder, K. \& Hallett, L. (eds.), Audience transformations: Shifting audience positions in late modernity. London: Routledge, pp. 123-141.

Ceruzzi, P. E. (1998). A history of modern computing. Cambridge Mass.: MIT Press.

Coover, R. (1992). The end of books. New York Times Book Review, June 21, $1,23-25$.

Coover, R., et al. (1993). The Hypertext Hotel. Providence, Mass: Brown University. Accessed 25.11.2013. URL: http://netlern.net/hyperdis/hyphotel/.

Cornis-Pope, M. (2000). Hypertextual and networked communication in undergraduate literature classes: Strategies for an interactive critical pedagogy. In Hickey, D. \& Reiss, D. (eds.), Learning literature in an era of change. Sterling, VA: Stylus, pp. 152-67.

Crosby, B. (1995), Convivial cybernetics devices: From vacuum tube flip-flops to the singing Altair. An interview with Lee Felsenstein (Part 1). The analytical engine. Newsletter of the Computer History Association of California, 3 (1), November 1995. Accessed 28.07.2013. URL: http://opencollector.org/history/homebrew/engv3n1.html.

Delany, P. \& Landow, G. P (eds.) (1991). Hypermedia and literary studies. London, Cambridge, Mass.: MIT Press.

Delany, P. \& Landow, G. P. (eds.) (1993). The digital word: Text-based computing in the humanities. London, Cambridge, Mass.: MIT Press. 
Deleuze, G. \& Guattari, F. (1980). Mille plateaux. Capitalisme et schizophrénie [A thousand plateaus: Capitalism and schizophrenia]. Paris: Minuit.

Dezeuze, A. (2010). The 'do-it-yourself' artwork: Participation from Fluxus to new media. Manchester: Manchester University Press.

Douglas, J. Y. (1994). I have said nothing. The Eastgate Quarterly Review of Hypertext, I, (2).

Douglas, J. Y. (2000). The end of books - Or books without end? Reading interactive narratives. Ann Arbor: University of Michigan Press.

Eco, U. (1962). Opera aperta. Forma e indeterminazione nelle poetiche contemporanee [The open work]. Milano: Bompiani.

Ensslin, A. (2007). Canonizing hypertext: Eplorations and constructions. London: Continuum.

Eruli, B. (ed.) (1994). Attenzione al potenziale! Il gioco della letteratura. Firenze: Marco Nardi.

Flichy, P. (1995). L’innovation technique. Paris: La Découverte.

Flichy, P. (1999). The construction of new digital media. New media \& society, 1(1), 33-39.

Flichy, P. (2001), L'imaginaire d'Internet [The internet imaginaire]. Paris: La Découverte.

Foster, H. (ed.) (1985). Postmodern culture. London: Pluto.

Foucault, M. (1969). Qu'est-ce qu'un auteur? [What is an author?]. Bulletin de la Societé Française de Philosophie, 43, 73-95.

Gere, C. \& Gardiner, H. (2010). Art practice in a digital culture. Digital research in the arts and humanities. London: Ashgate.

Gillespie, W., Marquardt, F., Rettberg, S. \& Stratton, D. (1998). The unknown. Accessed 20.11.2013. URL: http://unknownhypertext.com.

Gitelman, L. (1999). Scripts, grooves, and writing machines: Representing technology in the Edison Era. Palo Alto, Ca: Stanford University Press.

Graham, B. (2010). What kind of participative system? Critical vocabularies from new media art. In Dezeuze, A. (ed.), The 'Do-it-Yourself' artwork: Participation from Fluxus to new media. Manchester: Manchester University Press, pp. 281-305.

Griswold, W. (1994). Cultures and society in a changing world. Thousand Oaks: Sage. 
Guedj, R. A, ten Hagen, P. J. W., Hopgood, F. R., Tucker, H. A. \& Duce, D. A. (eds.) (1980). Methodology of interaction. Amsterdam: North Holland.

Hamilton, J. W. (2003). Remaking media participation in Early Modern England. Journalism, 4(3), 293-313.

Haraway, D. (1991). Simians, cyborgs, and women: The reinvention of nature. London, New York: Routledge.

Hayles, N. K., Montfort, N., Rettberg, S. \& Strickland, S. (eds.) (2006). Electronic literature collection. Volume One. College Park, Maryland: Electronic Literature Organization. Accessed 28.07.2013. URL: http://collection.eliterature.org/1/aux/about.html.

Hayles, K. N. (2002). Writing machines. Cambridge, London: MIT Press.

Illich, I. (1973). Tools for conviviality. New York: Harper \& Row.

Jackson, S. (1994). Patchwork girl. Cambridge, Mass.: Eastgate Systems.

Jameson, F. (1984). Postmodernism, or the cultural logic of late capitalism.

New left review, 146, July-August, 53-92.

Jenkins, H. \& Carpentier, N. (2013). Theorizing participatory intensities: A conversation about participation and politics. Convergence: The international journal of research into new media technologies, 19(3), 265-286.

Joyce, M. (1988). Siren shapes: Exploratory and constructive hypertexts. Academic computing, 3(4), 10-42.

Joyce, M. (1992). Afternoon: A story. Cambridge Mass.: Eastgate Systems.

Landow, G. P. (1992). Hypertext: The convergence of contemporary critical theory and technology. Baltimore, London: Johns Hopkins University Press.

Landow, G. P. (ed.) (1994). Hyper/text/theory. Baltimore, London: Johns Hopkins University Press.

Landow, G. (2006). Hypertext 3.0: Critical theory and new media in the age of globalization. Baltimore: The Johns Hopkins University Press.

Lanham, R. (1989). The electronic word: Literary study and the digital revolution. New literary history, 20(2), 265-290.

Lévy, P. (1995). Qu'est-ce que le virtuel? [Becoming virtual]. La Découverte, Paris.

Levy, S. (1984). Hackers: Heroes of the computer revolution. New York: Bantam. Liestøl, G. (1994). Wittgenstein, Genette, and the reader's narrative in hypertext. In Landow, G. P. (ed.), Hyper/text/theory. Johns Hopkins University Press, Baltimore, pp. 87-120. 
Marvin, C. (1998). When old technologies were new: Thinking about electric communication in the late nineteenth century. New York: Oxford University Press.

McDaid, J. (1991). Uncle Buddy's phantom funhouse. Cambridge, Mass.: Eastgate Systems.

MacPhail, W. (1991). Hypertext and journalism: Towards a new mass medium. In Berk, E. \& Devlin, J. (eds.), Hypertext/Hypermedia handbook. New York: Intertext/McGraw-Hill, pp. 460-64.

McGann, J. (2001). Radiant textuality: Literature after the World Wide Web. New York: Palgrave Macmillan.

McHale, B. (1987). Postmodernist fiction. London, New York: Methuen.

McMillan, S. J. (2002). Exploring models of interactivity from multiple research traditions: Users, documents and systems. In Livingstone, S. \& Liewrouv, L. H. (eds.), The handbook of new media. London: Sage, pp. 199-236.

Markus, M. (1990). Toward a "critical mass" theory of interactive media. In Fulk, J. \& Steinfeld, C. (eds.), Organization and communication technology. Newbury Park, CA: Sage, pp. 194-218.

Meyrowitz, N. (1989). Hypertext - does it reduce cholesterol, too?. In AAVV (1989), Hypertext '89. Proceedings. New York: ACM.

Montfort, N. (2003). Twisty little passages: An approach to interactive fiction. Cambridge, Mass.: MIT Press.

Moulthorpe, S. (1991a). Victory garden. Cambridge Mass.: Eastgate Systems. Moulthrop, S. (1991b). Special hypertext section. Writing on the edge, 2(2), 78-159.

Moulthrop, S. (1991c). Beyond the electronic book: A critique of hypertext rhetoric. In Furuta, R. K. \& Stotts, D. P. (eds.), Hypertext '91: Third ACM conference on hypertext. Proceedings. December 15-18, San Antonio, Texas. New York: ACM., pp. 291-298.

Moulthrop, S. (1991d). Toward a paradigm for reading hypertexts: Making nothing happen in hypermedia fiction. In Berk, E. \& Devlin, J. (eds), Hypertext/Hypermedia handbook. New York: Intertext/McGraw-Hill, pp. $65-78$.

Moulthrop, S. (1994). Rhizome and resistance: Hypertext and the dreams of a new culture. In George P. (ed.), Hyper/text/theory. Baltimore, London: Johns Hopkins University Press, pp. 299-319. 
Murray, J. M. (1997). Hamlet on the Holodeck: The future of narrative in cyberspace. New York: Free Press.

Nelson, T. H. (1974). Computer libldream machines. Theodor Holm Nelson. Rev. edition Seattle: Microsoft.

Nelson, T. H. (1977). The home computer revolution. Theodor Holm Nelson.

Nelson, T. H. (1990). Literary machines 90.1. Theodor Holm Nelson. Rev. edition Sausalito: Mindful Press.

Nelson, T. H. (1992). Opening Hypertext: A memoir. In Tuman, M. C. (ed.), Literacy online: The promise (and peril) of reading and writing with computers. Pittsburg: University of Pittsburg Press, pp. 43-57.

Nyce, J. M. \& Kahn, P. D. (eds.) (1991). From Memex to hypertext: Vannevar Bush and the mind's machine. San Diego: Academic.

Pasquali, F. (2003). I nuovi media fra tecnologie e discorsi sociali. Roma: Carocci. Pomian, J. \& Souchier, E. (1988). Les machines écrivantes ou l'écriture virtuelle. Traverses, 44-45, 108-119.

Popper, F. (1975). Art, action and participation. London, New York: Studio Vista and New York University Press.

Rheingold, H. (2000). Tools for thought. Cambridge Mass.: MIT Press. Accessed 28.07.2013. URL: http://www.rheingold.com/texst/tft/index.

Simpson, J. \& Weiner E. (eds.) (1993). Oxford English Dictionary Additions Series, vol. II. Oxford: Clarendon Press.

Ryan, M. (2005). Peeling the onion: Layers of interactivity in digital narrative texts. Accessed 28.07.2013. URL: http://users.frii.com/mlryan/onion.htm.

Turkle, S. (1984). The second self: Computers and the human spirit. New York: Simon \& Schuster.

Ulmer, G. L. (1990). Teletheory: Grammatology in the age of video. London, New York: Routledge.

van Dijck, J. (2013). The culture of connectivity: A critical history of social media. London: Oxford University Press.

Wardrip-Fruin, N. \& Montfort, N. (eds.) (2003). The new media reader. Cambridge, Mass.: MIT Press.

Williams, R. (1976). Keywords: A vocabulary of culture and society. London: Fontana.

Woolley, B. (1992). Virtual worlds: A journey in hype and hyperreality. London: Blackwell. 